\title{
FACTORS ASSOCIATED WITH INTUBATION EXTENDED IN PATIENTS WHO UNDEWENT A HEART SURGERY
}

\author{
FATORES ASSOCIADOS À INTUBAÇÃO PROLONGADA EM PACIENTES \\ SUBMETIDOS À CIRURGIA CARDÍACA
}

\author{
Mariana Pereira CARVALHO ${ }^{1}$; Raissa Bianca LUIZ $^{2}$; Erica Vieira de ANDRADE ${ }^{3}$; \\ Elizabeth BARICHELLO ${ }^{4}$; Karoline Faria de OLIVEIRA ${ }^{5}$; \\ Kleiton Nascimento GONÇALVES ${ }^{6}$; Luciana Falcão da CRUZ $^{7}$; \\ Suzel Regina Ribeiro CHAVAGLIA ${ }^{8 ;}$ Maria Helena BARBOSA ${ }^{9}$ \\ 1. Graduated in Nursing from the Universidade Federal do Triângulo Mineiro - UFTM, Uberaba, MG, Brazil.
} mari.p.c_enf@hotmail.com; 2. Nurse, Master in Health Care from the UFTM, Uberaba, MG, Brazil; 3 Nurse, Master in Health Care from the UFTM, Uberaba, MG, Brazil; 4. PhD in Nursing, Adjunct Professor of the UFTM, Uberaba, MG, Brazil; 5. Nurse, Master in Health Care from the UFTM, Uberaba, MG, Brazil; 6. Nurse, Master in Health Care from the UFTM, Uberaba, MG, Brazil; 7. Graduated in Nursing from the UFTM, Uberaba, MG, Brazil; 8. PhD in Nursing, Associate Professor of the DEAH and of the PPGAS of the UFTM, Uberaba, MG, Brazil; 9. PhD in Nursing in Adult Health, Associate Professor of the UFTM, Uberaba, MG, Brazil.

\begin{abstract}
This study was accomplished in order to identify the factors associated with prolonged intubation in patients who underwent cardiac surgery. This is a retrospective, analytical study, with a quantitative approach, performed in a large teaching hospital in the municipality of Uberaba (Minas Gerais). The data were collected from records of patients who underwent cardiac surgery. In order to identify the factors that may be associated with a prolonged intubation, a bivariate and a latter multivariate analysis were performed. The significance level was 0.05 . the study population was constituted by 460 individuals. From these, $150(32.6 \%)$ had prolonged intubation time (over 24 hours). The majority were male $(60.9 \%)$ and the average age was 55.60 years $( \pm 12.9)$. The results also showed that age over 60 years, the occurrence of pulmonary infection, the presence of comorbidities, intraoperative complications and the duration of the cardiopulmonary bypass were associated with the occurrence of prolonged intubation in these patients. Considering that prolonged intubation can often contribute to the occurrence of other complications in the postoperative period of a cardiac surgery, it is emphasized the importance of a careful preoperative evaluation. The findings of this study may contribute to the adoption of preventive measures in the clinical practice, with a view to the patient's safety and the quality of care.
\end{abstract}

KEYWORDS: Thoracic surgery. Risk factors. Intratracheal intubation

\section{INTRODUCTION}

With the advent of cardiac surgery (CS), the survival of the patients with cardiovascular disease has increased considerably. However, this procedure is considered large and complex and can evolve with postoperative complications (LEDUR et al., 2011).

At the end of a CS, the patient should remain on mechanical ventilation (MV) until the reestablishment of his thermodynamic condition and he recovers the level of consciousness (LAIZO; DELGADO; ROCHA, 2010). Endotracheal intubation is a procedure performed to maintain MV and respiratory support. However, this procedure is not free from side-effects and associated complications (NASCIMENTO et al., 2015), these being directly proportional to the procedure duration.

Keeping the endotracheal tube (ETT) for more than six hours, which may vary from six to 48 hours postoperatively, is considered a delay in the extubation process (LAIZO; DELGADO; ROCHA, 2010; SOARES et al., 2011).

It is noted that the increase in the patient's stay on the mechanical ventilator is directly related to the incidence of lung injury, an increased exposure to offending microorganisms due to the need for performing invasive procedures, thus enabling the development of infections and increasing the ICU stay, as well as resulting in higher hospital costs (SILVA; BARBOSA, 2012).

In order to improve the quality of the care provided to patients submitted to CS and to prevent the occurrence of complications associated with prolonged intubations, the nurse should know the risk factors, as well as participate actively in this process, grounded in theoretical and scientific knowledge. Based on these, the aim of this study was to identify the factors associated with prolonged intubation in patients who underwent a CS. 


\section{MATERIAL AND METHODS}

This is a retrospective, analytical study with a quantitative approach. The study was conducted in a public teaching hospital in Uberaba, Minas Gerais (Brazil). This institution is characterized as a large tertiary hospital that serves highly complex patients. It has 290 beds and serves medical and surgical specialties.

The population consisted of patients who underwent a cardiac surgery (CS) in the period ranging from July 2005 to July 2010 that met the inclusion criteria: age greater than or equal to 18 years who underwent CS by longitudinal median sternotomy. Patients whose medical record numbers have not been located or identified and those who died intraoperatively or within 48 hours after the surgery were excluded.

The data were collected by using the medical records of the patients submitted to CS from the hospital's Medical Records and Statistical Service. It was used a data collection instrument that addressed clinical and epidemiological aspects as well as those related to the surgical procedure performed. This instrument was submitted to three judges for the apparent and content validation. The participant judges had the $\mathrm{PhD}$ title and expertise on the subject addressed in this study. The data were collected by the researchers after training and planning for the collection.

Once collected, the data were entered into an electronic spreadsheet of Windows ${ }^{\circledR}$ Excel ${ }^{\circledR}$ program, that was validated by double entry and exported to the Statistical Package for the Social Sciences (SPSS) version 19.0 for Windows ${ }^{\circledR}$ for processing and analysis.

The qualitative variables were analyzed according to descriptive statistics through the distribution of the absolute and the percentage frequency, while for the quantitative variables it was used the descriptive measures of centrality (mean) and dispersion (standard deviation, minimum and maximum values).

In order to identify factors that may be associated with the occurrence of a prolonged intubation, it was performed initially a bivariate analysis by using the chi-square test and the measures of association (relative risk and odds ratio). Statistically significant associations were considered, $p$ value $<0.05$. Subsequently, the multivariate analysis by logistic regression was used. For this, it was considered the variables that presented in the bivariate analysis a $p$ value $<0.01$. In the multivariate analysis, the statistical significance level adopted was 0.05 .
Researchers that address the prolonged intubation subject consider the lack of consensus on the definition of the issue (TOTONCHI et al., 2014). Some authors, though, consider prolonged intubation as a ventilator dependence during a period larger than 24 hours, or a necessity of reintubation that totalizes a total time of intubation over $24 \mathrm{~h}$ (WIDYASTUTI et al., 2012). Thus, it is emphasized that in this study prolonged intubation was considered as a dependence on mechanical ventilator with a time longer than 24 hours.

This project is a part of a larger work entitled "Analysis of Hospital Infection Occurrences in Patients Who Underwent a Cardiac Surgery," approved by the Ethics and Research Committee from the Federal University of Triângulo Mineiro under Opinion No. 1611, respecting Resolution No. 196/96 (BRAZIL, 1996) on research involving human beings.

The Free and Informed Consent Term was not used, considering that the data were obtained from the patient's medical records and the hospital infection information forms and that many of the patients live in other cities or have died, which makes the signing of the Term unviable.

\section{RESULTS}

The study population consisted of 460 individuals. From these, $150(32.6 \%)$ had a prolonged intubation (larger than 24 hours).

From the subjects studied, most, 280 $(60.9 \%)$, were male, and the average age was 55.60 years $( \pm 12.9)$, ranging from 18 to 81 years. It was observed that the age group with the highest prevalence ranged from 50 to 59 years in 146 (31.7\%) patients. Most patients came from the city of Uberaba-MG, 304 (66.1\%).

As for comorbidities, it was observed that most patients, 325 (70.7\%), showed Systemic Arterial Hypertension (SAH); followed by Diabetes Mellitus (DM), 105 (22.8\%), and COPD, 52 (11.3\%). In the population studied, the Body Mass Index (BMI) was $25.6 \mathrm{~kg} / \mathrm{m}^{2}( \pm 4.2)$ with a variation ranging from 14.9 to $40.3 \mathrm{~kg} / \mathrm{m}^{2}$. It was observed that $122(26.5 \%)$ patients were overweight and 114 (24.8\%) were eutrophic. It is noteworthy that for $171(37.2 \%)$ patients it was not possible to calculate the BMI due to the lack of information in the medical records.

Related to smoking, $146 \quad(31.7 \%)$ were smokers, $141(30.7 \%)$ did not use tobacco, 106 (23.0\%) were former smokers and 67 (14.6\%) did not have this information in their medical records. 
A prior CS had been performed in 41 $(8.9 \%)$ patients, and $37(8.0 \%)$ patients had a preexisting infectious focus.

The study population had a preoperative hospital stay mean time of 7.2 days $( \pm 7.8)$, with a variation ranging from one to 54 days. It was observed that $110(23.9 \%)$ patients had a preoperative hospitalization in an Intensive Care Unit (ICU), which presented in this unit an average length of stay of 5.3 days $( \pm 4.7)$, varying from one to 36 days.

The Coronary Artery Bypass Grafting (CABG) was the most prevalent procedure, 218 (47.4\%), followed by mitral and aortic valve replacement, $83(18.0 \%)$ and 69 (15.0\%), respectively.

Most surgical procedures, 452 (98.3\%), were classified as elective, and the surgery mean duration was 230.30 minutes $( \pm$ 62.1). Extracorporeal Circulation (ECC) was used in 449 (97.6\%) cardiac surgeries, with an average duration of 78.0 minutes $( \pm 33.1)$, with a variation raging from ten to 260 minutes.

Regarding the aspects related to the intraoperative period, $34(7.4 \%)$ had a total of 46 complications during the surgery, which resulted in an average of 1.3 complications per patient. The most frequent intraoperative complication was hypotension, evidenced in eight $(17.5 \%)$ patients.

As for the aspects related to the postoperative period, it was found that the average stay in the ICU was 7.6 days $( \pm 7.8)$, with a variation ranging from two to 70 days, and the total time of postoperative hospital stay was 11.9 days ( \pm 10.3 ), varying from three to 76 days.

The average time of postoperative intubation was 26.1 hours $( \pm 43.9)$, with a variation ranging from four to 469 hours, and 62 (13.5\%) patients were reintubated.

Regarding the postoperative complications, $230(50.0 \%)$ patients had a total of 514 complications, resulting in an average of 2.2 complications per patient.

In the population studied, the respiratory tract infection showed a higher incidence, 95 (20.6\%).

Regarding the evolution of the patients, it was observed that most, 407 (88.5\%), progressed to hospital discharge, 52 (11.3\%) patients died and one $(0.2 \%)$ was transferred to another hospital.

In the bivariate analysis, the variables that had a statistically significant association $(p<0.05)$ with the prolonged intubation outcome were the age ( $\mathrm{p}<0.001)$, the presence of comorbidities ( $\mathrm{p}$ $<0.001)$, a surgery duration greater than 180 minutes $(\mathrm{p}<0.001)$, the occurrence of pulmonary infection $(\mathrm{p}<0.001)$, complications during surgery $(\mathrm{p}<0.001)$ and the duration of the ECC ( $\mathrm{p}<0.001)$, Table 1 .

In the Table 1 below, it can be seen the preliminary bivariate analysis of the risk factors for prolonged intubation.

Table 1. Bivariate table of risk factors associated with prolonged intubation in patients undergoing cardiac surgery. Uberaba-MG, 2013.

\begin{tabular}{|c|c|c|c|c|c|}
\hline \multirow{2}{*}{ Variable } & \multicolumn{2}{|c|}{ Intubation extended } & \multirow{2}{*}{$\begin{array}{l}\text { Relative Risk } \\
\text { (CI 95\%) }\end{array}$} & \multirow{2}{*}{$\begin{array}{c}\text { Odds ratio } \\
\text { (CI 95\%) }\end{array}$} & \multirow{2}{*}{ P value } \\
\hline & $\begin{array}{r}>24 \text { hours } \\
\mathrm{N}(\%)\end{array}$ & $\begin{array}{r}<24 \text { hours } \\
\mathrm{N}(\%)\end{array}$ & & & \\
\hline \multicolumn{6}{|l|}{ Sex } \\
\hline Male & $91(32,5 \%)$ & $189(67,5 \%)$ & $0,99(0,76-1,30)$ & $0,99(0,66-1,47)$ & 0,951 \\
\hline Female & $59(32,8 \%)$ & $121(67,2 \%)$ & & & \\
\hline \multicolumn{6}{|l|}{ Age } \\
\hline Elderly & $84(45,4 \%)$ & $101(54,6 \%)$ & $1,89(1,45-2,46)$ & $2,63(1,76-3,93)$ & $<0,001$ \\
\hline Adult & $66(24 \%)$ & $209(76 \%)$ & & & \\
\hline \multicolumn{6}{|l|}{ Morbidities } \\
\hline None & $14(14,9 \%)$ & $80(85,1 \%)$ & $0,40(0,24-0,66)$ & $0,30(0,16-0,54)$ & $<0,001$ \\
\hline One or more & $136(37,2 \%)$ & $230(62,8 \%)$ & & & \\
\hline \multicolumn{6}{|c|}{ Duration of surgery } \\
\hline $\begin{array}{l}>\text { than } 180 \\
\text { minutes }\end{array}$ & $133(37,9 \%)$ & $218(62,1 \%)$ & $2,43(1,54-3,84)$ & $3,30(1,88-5,78)$ & $<0,001$ \\
\hline $\begin{array}{l}<\text { than } 180 \\
\text { minutes }\end{array}$ & $17(15,6 \%)$ & $92(84,4 \%)$ & & & \\
\hline \multicolumn{6}{|c|}{ Occurrence of Pulmonary Infection } \\
\hline Yes & $59(62,1 \%)$ & $36(37,9 \%)$ & $2,49(1,96-3,16)$ & $4,93(3,06-7,95)$ & $<0,001$ \\
\hline No & $91(24,9 \%)$ & $274(75,1 \%)$ & & & \\
\hline
\end{tabular}




\begin{tabular}{lccccc} 
One or more & $19(57,6 \%)$ & $14(42,4 \%)$ & $1,88(1,35-2,60)$ & $3,06(1,49-6,30)$ & $<0,001$ \\
$\begin{array}{l}\text { None } \\
\text { Chronic Obstructive Pulmonary Disease }\end{array}$ & $131(30,7 \%)$ & $296(69,3 \%)$ & & \\
$\begin{array}{l}\text { Yes } \\
\text { Yes }(42,3 \%)\end{array}$ & $30(57,7 \%)$ & $1,35(0,95-1,91)$ & $1,60(0,89-2,89)$ & 0,11 \\
No & $128(31,4 \%)$ & $280(68,6 \%)$ & & & \\
$\begin{array}{l}\text { Duration of extracorporeal circulation } \\
>120 \text { minutes }\end{array} 28(58,3 \%)$ & $281(70,1 \%)$ & $1,95(1,47-2,58)$ & $3,28(1,78-6,05)$ & $<0,001$ \\
$<120$ minutes & $120(29,9 \%)$ & $167(66,3 \%)$ & & & \\
Smoking & & & & & \\
Yes and Ex & $6(75,0 \%)$ & $2(25,0 \%)$ & $1,08(0,80-1,46)$ & $1,12(0,72-1,74)$ & 0,060 \\
No & $89(19,7 \%)$ & $363(80,3 \%)$ & & & \\
\hline
\end{tabular}

Source: research data

In the multivariate logistic regression analysis, the age, the occurrence of pulmonary infection, morbidity, complications during surgery and the duration of the ECC continued to show a statistically significant association $(p<0.05)$ with the occurrence of prolonged intubation and were considered risk factors for this outcome, as shown in the Table 2.
Regarding the surgery duration, the incidence of a prolonged intubation in a surgery with duration $>180$ minutes was $37.9 \%$, and $15.6 \%$ in a surgery with duration shorter than 180 minutes; there was no statistically significant association, being $\mathrm{p}=0.30$ (Table 2 ).

The logistic regression analysis of the factors associated with a prolonged intubation is shown in Table 2.

Table 2. Logistic regression analysis of factors associated with prolonged intubation in patients undergoing cardiac surgery. Uberaba-MG, 2013.

\begin{tabular}{|c|c|c|c|c|}
\hline \multirow[t]{2}{*}{ Variable } & \multicolumn{2}{|c|}{ Intubation Extended } & \multirow[t]{2}{*}{ Odds Ratio } & \multirow[t]{2}{*}{$P$ value } \\
\hline & $\begin{array}{c}>24 \text { Hours } \\
\mathrm{N}(\%)\end{array}$ & $\begin{array}{c}<24 \text { Houes } \\
\mathrm{N}(\%)\end{array}$ & & \\
\hline \multicolumn{5}{|l|}{ Age } \\
\hline Elderly & $84(45,4 \%)$ & $101(54,6 \%)$ & $2,08(1,3-3,2)$ & 0,001 \\
\hline Adult & $66(24 \%)$ & $209(76 \%)$ & & \\
\hline \multicolumn{5}{|l|}{ Morbidities } \\
\hline None & $14(14,9 \%)$ & $80(85,1 \%)$ & $2,3(1,05-5,02)$ & 0,04 \\
\hline One or more & $136(37,2 \%)$ & $230(62,8 \%)$ & & \\
\hline \multicolumn{5}{|c|}{ Duration of surgery } \\
\hline$>180$ minutes & $133(37,9 \%)$ & $218(62,1 \%)$ & $1,3(0,8-2,1)$ & 0,30 \\
\hline$<180$ minutes & $17(15,6 \%)$ & $92(84,4 \%)$ & & \\
\hline \multicolumn{5}{|c|}{ Occurrence of Pulmonary Infection } \\
\hline Yes & $59(62,1 \%)$ & $36(37,9 \%)$ & $2,6(1,5-4,5)$ & $<0,001$ \\
\hline No & $91(24,9 \%)$ & $274(75,1 \%)$ & & \\
\hline \multicolumn{5}{|c|}{ Complications of Intra Operative } \\
\hline One or more & $19(57,6 \%)$ & $14(42,4 \%)$ & $2,6(1,2-5,7)$ & 0,02 \\
\hline None & $131(30, \%)$ & $296(69,3 \%)$ & & \\
\hline \multicolumn{5}{|c|}{ Duration of extracorporeal circulation } \\
\hline$>120$ minutes & $28(58,3 \%)$ & $281(70,1)$ & $1,71(1,01-2,9)$ & 0,04 \\
\hline$<120$ minutes & $120(29, \%)$ & $167(66,3)$ & & \\
\hline
\end{tabular}

Source: research data

\section{DISCUSSION}

In this study, there was a predominance of males $(60.9 \%)$, which corroborates other findings (FINZI, 2010; WIDYASTUTI et al., 2012; OLIVEIRA et al., 2013; TOTONCHI et al., 2014).
The mean age was 55.60 years and the predominant age group was 50-59 years. In a research that evaluated predictors of a prolonged MV in the cardiac surgery postoperative period, the mean age of the population studied was $56+/-14$ years (TOTONCHI et al., 2014). 
However, in the literature it was found results that differ from those observed in the present study. A sample of 447 patients who underwent CS in a large university hospital obtained an elder prevalence, aged equal or over 65 years (FINZI, 2010).

Regarding comorbidities, most patients had systemic arterial hypertension (SAH). A similar result was found in a study conducted at the Cardiology Institute of the Federal District, which aimed to assess individual and intraoperative risk factors for a prolonged stay in the ICU and in the infirmary, in which 87 patients $(83.7 \%)$ had SAH and 42 (40 4\%) had diabetes mellitus type II (OLIVEIRA et al., 2013).

In a study conducted in Norway that included 4994 patients who underwent a CS between 2000 and 2007, the most prevalent comorbidity was diabetes mellitus type II in $48.8 \%$ of the patients (WIDYASTUTI et al., 2012).

In this study, the mean BMI was $25,6 \mathrm{~kg} / \mathrm{m}^{2}$. Similar findings were found in a study that aimed to evaluate the perioperative risk factors for a prolonged hospitalization, in which the mean BMI was $27 \mathrm{~kg} / \mathrm{m}^{2}$ (OLIVEIRA et al., 2013).

As regards to smoking habits, there was a higher frequency of smoking patients. It was found that the results are consistent with those observed in the literature, given the high prevalence of smokers in other studies (OLIVEIRA et al., 2013; FONSECA; VIEIRA; AZZOLIN, 2014).

Regarding the type of surgery, coronary artery bypass grafting (CABG) was the most prevalent. Similar results were found in other studies (FINZI, 2010; WIDYASTUTI et al., 2012; LAPAR et al., 2013.). While the benefits of this procedure are patent, such as the increase in the patient survival, it is not risk-free, being of extremely importance the pre and post-operative evaluation of these patients in order to identify risk factors and to plan an individualized and preventive care.

Related to previous focus of infection, it was noted a higher incidence of respiratory tract infection. This data corroborates those presented in other studies, where there was also a higher incidence of lung infection (CORREA et al., 2010; SOARES et al., 2011; OLIVEIRA et al., 2013.).

As for the duration of the surgery, the average time was 3.8 hours. A similar finding was found in another research (FINZI, 2010). The changes in the lung function may be related to the CS time, leading to a decreased lung expansion and to further damages, such as atelectasis and pneumonia (BARROS et al., 2010), that negatively influences on the ventilation time.

As for the endotracheal intubation, the average time was 26.1 hours. A lower average was found in a study performed with 5027 patients who underwent a CS, where the average intubation time was 3.5 hours (WIDYASTUTI et al., 2012). A research conducted at the Rajei Cardiovascular Medial and Research Center with 743 patients showed that $45(6.05 \%)$ remained on mechanical ventilation for more than 48 hours (TOTONCHI et al., 2014).

The identification of the factors that may be associated with a prolonged intubation of patients submitted to a CS during the preoperative assessment can prevent the onset of complications in the postoperative period (SOARES et al., 2011).

Regarding the postoperative complications, half of the patients had at least one complication. A study of the medical records of the patients who underwent a CS showed that most of the subjects had some sort of complication. Among them it stood out pulmonary complications, especially acute respiratory failure, mechanical ventilation for more than 48 hours after surgery and pleural effusion, followed by cardiac and neurological complications (SOARES et al., 2011).

As for the evolution of the patients in the postoperative period, it was observed that most evolved to hospital discharge and $11.3 \%$ of the patients died. In a study aimed to develop a pre- and intraoperative model to predict the duration of the stay in the ICU, conducted with 5027 patients, 244 died, $66(27 \%)$ within 30 days or during the primary hospitalization (WIDYASTUTI et al., 2012).

In the present study, the patients aged over 60 years were considered as a risk factor for a prolonged intubation, being 2.08 times more likely to be intubated for a longer time, as compared to adults.

These individuals are more vulnerable and have changes in their health status characterized by diversity and complexity, with a higher incidence of chronic diseases and respiratory disorders (MARIN; SANTANA; MORACVICK, 2012), which may predispose to the need for more time on mechanical ventilation.

There was an association of lung infection with prolonged intubation. A study conducted in a large hospital in the interior of São Paulo, Brazil, showed that the presence of pulmonary infections in the postoperative period was associated with a longer MV use (CORREA et al., 2010).

Having one or more morbidities was statistically associated with a prolonged intubation. 
Patients with one or more comorbidities were 2.6 more likely to be subjected to a prolonged intubation as compared to those who did not exhibit any morbidity. In a case-control study with 104 patients who underwent a CS, the presence of comorbidities, such as diabetes and smoking, was a predictor for an increased time of stay in the ICU (OLIVEIRA et al., 2013).

It is noteworthy that, during the surgery, patients who had one or more complications were 2.6 more likely to remain intubated for a longer time as compared to those who did not have any complications in this period. The complications that arise from the surgical manipulation itself, such as the ECC use, the anesthesia effects and that are caused by the complexity of the surgery itself, can lead to the occurrence of other severities, thus predisposing to the need for more time under MV (AULER JUNIOR et al., 2007).

The ECC duration was a risk factor for the occurrence of a prolonged intubation. A study found that a longer ECC procedure is related to a longer time on the mechanical ventilation (FONSECA; VIEIRA; AZZOLIN, 2014).
CARVALHO, M. P. et al.

Surgeries longer than 180 minutes increase in 3.3 times the chances of experiencing a prolonged intubation as compared to a surgery time smaller than 180 minutes. The literature does not provide clear evidence about the relation between a prolonged intubation and the surgery time. However, a study showed that the greater the time that the patient stays in ECC, the longer is the MV time (FONSECA; VIEIRA; AZZOLIN, 2014).

\section{CONCLUSIONS}

Prolonged intubation was identified in $32.6 \%$ of patients who underwent CS.

The factors associated with a prolonged intubation in patients who underwent a cardiac surgery were: age (over 60 years), the occurrence of lung infection, the presence of comorbidities, complications during surgery and duration of ECC time longer than 120 minutes.

The findings of this study point to the importance of a careful preoperative evaluation so that measures can be implemented to prevent the occurrence of a prolonged intubation in patients who undergoes a cardiac surgery.

RESUMO: Este estudo foi realizado a fim de identificar os fatores associados à intubação prolongada em pacientes submetidos à cirurgia cardíaca. Trata-se de um estudo retrospectivo, analítico, com abordagem quantitativa. Foi realizado em um hospital de ensino de grande porte, no município de Uberaba (Minas Gerais). Os dados foram coletados dos prontuários dos pacientes que realizaram cirurgia cardíaca. Para identificar os fatores que podem estar associados à intubação prolongada realizou-se a análise bivariada e posteriormente a análise multivariada. O nível de significância foi de 0,05. A população deste estudo constituiu-se por 460 indivíduos. Destes, $150(32,6 \%)$ tiveram intubação prolongada (maior que 24 horas). A maioria era do sexo masculino $(60,9 \%)$ e a média de idade foi de 55,60 anos $( \pm 12,9)$. Os resultados também evidenciaram que idade acima de 60 anos, ocorrência de infecção pulmonar, presença de morbidades, intercorrências no intraoperatório e duração da circulação extracorpórea estavam associados à intubação prolongada nesses pacientes. Considerando que a intubação prolongada frequentemente pode corroborar para ocorrência de outras complicações no pós-operatório de cirurgias cardíacas, ressalta-se a importância da avaliação pré-operatória criteriosa. Os achados deste estudo poderão contribuir para que medidas preventivas possam ser adotadas na prática clínica, tendo em vista a segurança do paciente e qualidade do cuidado.

PALAVRAS-CHAVE: Cirurgia torácica. Fatores de risco. Intubação endotraqueal.

\section{REFERENCES}

AULER JUNIOR, J. O. C.; GALAS, F. R. B. G.; HAJJAR, L. A.; FRANCA, S. Ventilação Mecânica no intraoperatório. Jornal Brasileiro de Pneumologia, Brasília, v. 22, supl. 2, p. 137-141, 2007.

https://doi.org/10.1590/S1806-37132007000800009

BARROS, G. F.; SANTOS, C. S.; GRANADO, F. B.; COSTA, P. T.; LIMACO, R. P.; GARDENGHI, G. Treinamento muscular respiratório na revascularização do miocárdio. Revista Brasileira de Cirurgia Cardiovascular, São José do Rio Preto, v. 25, n. 4, p. 483-490, 2010. https://doi.org/10.1590/s010276382010000400011 
BRASIL. Ministério da Saúde . Conselho Nacional de Saúde. Diretrizes e normas regulamentadoras sobre pesquisa envolvendo seres humanos. Resolução 196. 1996. Brasília: CNS; 1996.

CORREA, P. R.; CATAI, A. M.; TAKAKURA, I. T.; MACHADO, M. N.; GODOY, M. F. Variabilidade da frequência cardíaca e infecções pulmonares pós revascularização miocárdica. Arquivos Brasileiros de Cardiologia, v. 95, n. 4, p. 448-456, 2010. https://doi.org/10.1590/S0066-782X2010005000123

FINZI, M. B. A. Infecções de sítio cirúrgico após cirurgias cardíacas em um hospital universitário mineiro: incidência, aspectos microbiológicos e epidemiológicos. 2010. 72 f. Dissertação (Mestrado em Parasitologia e Imunologia Aplicados) - Curso de Pós-Graduação em Parasitologia e Imunologia Aplicados, Universidade Federal de Uberlândia, Uberlândia, 2010.

FONSECA, L.; VIEIRA, F. N.; AZZOLIN, K. O. Fatores associados ao tempo de ventilação mecânica no pósoperatório de cirurgia cardíaca. Revista Gaúcha de Enfermagem, Porto Alegre, v. 35, n. 2, p. 67-72, 2014. https://doi.org/10.1590/1983-1447.2014.02.44697

LAIZO, A.; DELGADO, F. E. F.; ROCHA, G. M. Complicações que aumentam o tempo de permanência na unidade de terapia intensiva na cirurgia cardíaca. Revista Brasileira de Cirurgia Cardiovascular, São José do Rio Preto, v. 25, n. 2, p. 166-171, 2010. https://doi.org/10.1590/s0102-76382010000200007

LAPAR, D. J.; GILLEN, J.; CROSBY, I. K.; SAWYER, R. G.; LAU, C. L.; KRON, I. L.; AILAWADI, G. Predictors of operative mortality in cardiac surgical patients with prolonged intensive care unit duration. Journal of the American College of Surgeons, v. 216, n. 6, p. 1116-1123, 2013. https://doi.org/10.1016/j.jamcollsurg.2013.02.028

LEDUR, P.; ALMEIDA, L.; PELLANDA, L. C.; SCHAAN, B. D. Preditores de infecção em cirurgia de revascularização do miocárdio. Revista Brasileira de Cirurgia cardiovascular, São José do Rio Preto, v. 26, n. 2, p. 190-196, 2011.

MARIN, M. J. S.; SANTANA, F. H. S.; MORACVIVK, M. Y. A. D. Percepção de idosos hipertensos sobre suas necessidades de saúde. Revista da Escola de Enfermagem da USP, São Paulo, v. 46, n. 1, p. 103-110, 2012. https://doi.org/10.1590/S0080-62342012000100014

NASCIMENTO, M. S.; PRADO, C.; TROSTER, E. J.; VALÉRIO, N.; ALITH, M. B.; ALMEIDA, F. L. Fator de risco para estridor pós-extubação em crianças: o papel da cânula orotraqueal. Einstein, v. 13, n. 2, p.226231, 2015. https://doi.org/10.1590/S1679-45082015AO3255

OLIVEIRA K. L.; TURQUETTO, A. L. R.; TAUIL, P. L.; JUNQUEIRA-JUNIOR L. F.; PORTO, L. G. G. Risk factors for prolonged hospital stay after isolated coronary artery bypass grafting. Revista Brasileira de Cirurgia Cardiovascular, São José do Rio Preto, v. 28, n. 3, p. 353-363, 2013. https://doi.org/10.5935/16789741.20130055

SILVA, Q. C. G.; BARBOSA, M. H. Fatores de risco para infecção de sítio cirúrgico em cirurgia cardíaca. Acta Paulista de Enfermagem, São Paulo, v. 25, n. 2, p. 89-95, 2012. https://doi.org/10.1590/S010321002012000900014

SOARES, G. M. T.; FERREIRA, D. C. S.; GONÇALVES, M. P. C.; ALVES, T. G. S.; DAVID, F. L.; HENRIQUES, K. M. C.; RIANI, L. R. Prevalência das principais complicações pós-operatórias em cirurgias cardíacas. Revista Brasileira de Cardiologia, v. 24, n. 3, p. 139-146, 2011.

TOTONCHI, Z.; BAAZM, F.; CHITSAZAN, M.; SEIFI, S.; CHITSAZAN, M. Predictors of prolonged mechanical ventilation after open heart surgery. Journal of Cardiovascular and Thoracic Research, v. 6, n. 4, p. 211-216, 2014. https://doi.org/10.15171/jcvtr.2014.014

WIDYASTUTI, Y.; STENSETH, R.; WAHBA, A.; PLEYM, H.; VIDEM, V. Length of intensive care unit stay following cardiac surgery: is it impossible to find a universal prediction model? Interactive Cardiovascular and Thoracic Surgery, v. 15, p. 825-833, 2012. https://doi.org/10.1093/icvts/ivs302 